Running title: Improved quality of ray stored in slurry ice

\title{
Title: Evaluation of a slurry ice system for the commercialization of ray (Raja clavata): Effects on spoilage mechanisms directly affecting quality loss and shelf-life
}

\author{
Authors: Begoña Múgica ${ }^{\mathrm{a}}$, Santiago P. Aubourg ${ }^{\mathrm{a}}$, José M. Miranda ${ }^{\mathrm{b}}$, and Jorge \\ Barros-Velázquez ${ }^{\text {b,* }}$ \\ Affiliations: \\ ${ }^{\mathrm{a}}$ Department of Seafood Chemistry; Institute for Marine Research (IIM-CSIC), C/ \\ Eduardo Cabello 6, E-36208 Vigo, Spain \\ ${ }^{\mathrm{b}}$ Department of Analytical Chemistry, Nutrition and Food Science, School of Veterinary \\ Sciences, University of Santiago de Compostela, E-27002 Lugo, Spain; and

\begin{abstract}
*Corresponding author:
Professor Jorge Barros-Velázquez, Laboratory of Food Technology, Department of Analytical Chemistry, Nutrition and Food Science, School of Veterinary Sciences, University of Santiago de Compostela, E-27002 Lugo, Spain. Tel: +34-600942264; Fax: +34-986-649266; E-mail address: jbarros@lugo.usc.es
\end{abstract}

\begin{abstract}
The application of slurry ice, a biphasic system formed by small spherical ice crystals surrounded by seawater at subzero temperature, was evaluated as a new storage method for ray (Raja clavata), the elasmobranchious fish species that exhibits highest commercial value in the European food markets. This advanced technique was performed in parallel with respect to a control batch stored 10 days in flake ice for comparison purposes. The results obtained in the sensory analysis indicated a significant extension of the overall quality (A class fish) from three days (flake ice) to six days (slurry ice). The development of ammonia external odour was the limiting parameter in both batches and was correlated with the activity of the endogenous mechanisms involved in the degradation of proteins and non-protein-nitrogen (NPN) rather than with the activity of proteolytic microorganisms. Storage of ray in slurry ice significantly $(P<0.05)$ slowed down both biochemical (as estimated by the follow-up of the $\mathrm{pH}, \mathrm{TVB}-\mathrm{N}$ and $\mathrm{K}$ value evolution) and microbial degradation mechanisms (estimated by the development of psychrotrophes and mesophiles counts) in chilled ray muscle. According to the parameters evaluated, storage of ray in slurry ice extends the shelf-life of this elasmobranchious fish species due to a better maintenance of sensory, biochemical and microbiological quality, this facilitating its commercialization.
\end{abstract}

Keywords: Ray; Elasmobranchious fish; Chilled storage; Slurry ice; Shelf-life; Quality loss. 


\section{Introduction}

Aquatic food products suffer a rapid quality loss post-mortem due to a wide number of biochemical and microbial breakdown mechanisms. The slowing down of such mechanisms requires refrigeration immediately after the capture. In this sense, aquatic food products have traditionally been cooled and stored by means of flake ice (Nunes, Batista \& Morâo de Campos, 1992) or refrigerated seawater (Kraus, 1992). Recently the introduction of ice slurries has provided several advantages for the preservation of aquatic food products in this type of ice-water suspensions at subzero temperature (for a review: Piñeiro, Barros-Velázquez \& Aubourg, 2004). Slurry ice is a biphasic system consisting of spherical and microscopic ice crystals dispersed in refrigerated marine water that allows faster chilling rates due to its higher heat-exchange capacity, and a reduced physical damage to fish structures as compared with the aciculate crystals of flake ice. The complete coverage of the fish surface by the slurry ice mixture also allows a better protection of the fish material with respect to oxidation and dehydration events (Piñeiro, Barros-Velázquez \& Aubourg, 2004).

Since Chapman (1990) reported a better maintenance of quality of finfish stored onboard in slurry ice as compared with other chilling technologies, this technique has been successfully applied to fatty fish species such as tuna (Price, Melvin \& Bell, 1991) or sardine (Campos, Rodríguez, Losada, Aubourg \& Barros-Velázquez, 2005; Losada, Barros-Velázquez, Gallardo \& Aubourg, 2004), and to lean fish species such as seabass (Martinsdöttir, Valdimarsdöttir, Porkelsdöttir, Olafsdöttir \& Tryggvadöttir, 2002), hake (Rodríguez, Losada, Aubourg \& Barros-Velázquez, 2004; Losada, Piñeiro, BarrosVelázquez \& Aubourg, 2004) or turbot (Rodríguez, Barros-Velázquez, Piñeiro, Gallardo \& Aubourg, 2006). The practical advantages of slurry ice for the storage of Australian prawns (Chinivasagam, Bremner, Wood \& Nottingham, 1998), or shrimp stored on-board (Huidobro, López-Caballero \& Mendes, 2002) have also been reported. More recently, a slurry ice system and its combination with an antimelanosic agent have been evaluated for the storage of crustaceans (Losada, Rodríguez, Miranda, BarrosVelázquez \& Aubourg, 2006; Aubourg, Losada, Prado, Miranda \& Barros-Velázquez, 2007).

All such previous studies have confirmed that the rate of quality loss depends not only on the handling and storage conditions used but also on the nature of the fish species in question (Whittle, Hardy \& Hobbs, 1990; Olafsdöttir, Martinsdöttir, Oehlenschläger, Dalgaard, Jensen, Undeland, Mackie, Henehan, Nielsen \& Nilsen, 1997). In Spain, and indeed in other European countries, ray (Raja clavata) represents the most commercialized elasmobranchious fish species, mainly caught either at the European nearby coast and at the Gran Sol fishing bank (Xunta de Galicia, 2001; FAO, 2006). Thus, from the commercial point of view, ray specimens deserve considerable appreciation as a fresh consumable product because of its delicate and excellent sensory features (Pastoriza and Sampedro, 1994). However, sometimes the capture of ray in distant fishing banks usually means that the time elapsed between the catch and arrival at its destination may vary from one to eight days, underlining the need to optimise refrigeration parameters in order to provide consumers with fish of the highest quality possible. Moreover, the important mechanisms of ammonia generation occurring in ray muscle and mainly derived from the accelerated degradation of proteins and nonprotein-nitrogen may limit the commercialization period of this fish species (Vyncke, 1978; Finne, 1992) as a refrigerated product. Consequently, in this study we evaluated the effects of chilling ray in slurry ice on its shelf-life determined by means of sensory, 
1 biochemical and microbiological analyses. The results were compared with those

4 determined in parallel in a batch stored in flake ice for 10 days.

\section{Materials and methods}

\subsection{Slurry ice system used}

The slurry ice prototype (FLO-ICE, Kinarca S.A.U., Vigo, Spain) used in this study produced a slurry ice binary mixture consisting of $40 \%$ ice and $60 \%$ water, from filtered seawater (salinity: $3.3 \%$ ). The temperature of the slurry ice was $-1.5^{\circ} \mathrm{C}$. Flake ice was prepared with an Icematic F100 Compact device (CASTELMAC SPA, Castelfranco, Italy). The ray specimens were placed in either slurry or flake ice at a fish:ice ratio of $1: 1$, and stored for up to 10 days in a refrigerated room at $+2^{\circ} \mathrm{C}$. When required, the flake ice and the slurry ice mixture were renewed.

\subsection{Fish material, processing and sampling}

Specimens of ray (Raja clavata) were purchased the day they were caught from a local market in Vigo (Northwestern Spain) and kept under refrigeration for $1 \mathrm{~h}$ until arrival at our laboratory. The fish specimens were neither headed nor gutted. The length of the fish was in the 50-60 cm range and their weight was 700-900 g. The specimens were either chilled in slurry ice or in flake ice. The temperature of the ray specimens stored in slurry ice was in the range of $-0.5^{\circ} \mathrm{C}$ to $-1.0^{\circ} \mathrm{C}$, while that of the counterpart specimens stored in flake ice was in the range of $+0.5^{\circ} \mathrm{C}$ to $+1.0^{\circ} \mathrm{C}$. Whole specimens were taken from each batch on days $0,3,6,8$ and 10 . Once the intact specimens had been subjected to sensory analyses, the white muscle was aseptically dissected and used for microbiological and chemical analyses. All analyses were performed by triplicate.

\subsection{Sensory analyses}

Sensory analysis was performed by a panel formed by five experienced judges, according to official guidelines (Table 1) concerning fresh and refrigerated elasmobranchious fish (DOCE, 1989). Four categories were ranked: highest quality (E), good quality (A), fair quality (B), and unacceptable quality (C). Sensory evaluation of the ray specimens included the following parameters: exam of skin, eyes and gills, flesh consistency and ventral side aspect, and external odour.

\subsection{Microbiological analyses}

Samples of $25 \mathrm{~g}$ of white muscle were dissected aseptically from chilled ray specimens, mixed with $225 \mathrm{ml}$ of $0.1 \%$ peptone water, and homogenized in a stomacher (Seward Medical, London, UK) as previously described (Ben-Gigirey, Vieites Baptista de Sousa, Villa \& Barros-Velázquez, 1998, 1999). In all cases, serial dilutions from the microbial extracts were prepared in $0.1 \%$ peptone water (Oxoid Ltd., London, UK). Total aerobes were investigated by surface inoculation in plate count agar (PCA, Oxoid) after incubation at $30^{\circ} \mathrm{C}$ for $72 \mathrm{~h}$. Psychrotrophes were investigated in the same manner but incubation was carried out at $4^{\circ} \mathrm{C}$ for 7 days. Microorganisms exhibiting a proteolytic phenotype were investigated in casein-agar medium $\left(30^{\circ} \mathrm{C} / 48 \mathrm{~h}\right)$ (Phaff, 
Starmer, Lachance \& Ganter, 1994), as previously described (Ben-Gigirey, Vieites Baptista de Sousa, Villa and Barros-Velázquez, 2000).

\subsection{Biochemical analyses}

The evolution of $\mathrm{pH}$ values in ray muscle along storage time was determined by means of a 6-mm diameter insertion electrode (Crison, Barcelona, Spain).

Total volatile base-nitrogen (TVB-N) values were measured as previously reported (Aubourg, Sotelo \& Gallardo, 1997). Briefly, fish muscle (10 g) was extracted with 6\% perchloric acid and brought up to $50 \mathrm{ml}$-the TVB-N content being determined, following steam-distillation of the acid extracts rendered alkaline to $\mathrm{pH} 13$ with $20 \%$ $\mathrm{NaOH}$ - by titration of the distillate with $10 \mathrm{mM} \mathrm{HCl}$. The results were expressed as $\mathrm{mg}$ TVB-N/100 g muscle.

Nucleotide extracts were prepared according to the method of Ryder (1985) and were stored at $-30^{\circ} \mathrm{C}$ until analysis. Nucleotide analysis was performed by HPLC using a Beckman device provided with the programmable solvent module 126 (Beckman), and the scanning detector module 167 (Beckman) connected to System Gold software, version 8.1 (Beckman). Separations were accomplished on a reverse-phase Spherisorb ODS-2 $\mathrm{C}_{18} 250$ x $4.60 \mathrm{~mm}$ column (Waters, Milford, MA), with an internal particle diameter of $5 \mu \mathrm{m}$. The composition of the mobile phase was as follows: solvent A was composed of $0.04 \mathrm{M} \mathrm{KH}_{2} \mathrm{PO}_{4}+0.006 \mathrm{M} \mathrm{K}_{2} \mathrm{HPO}_{4}$, $\mathrm{pH} 7$; solvent $\mathrm{B}$ was acetonitrile. The solvents were filtered through a $0.45 \mu \mathrm{m}$ aqueous filter before use. Separations were carried out using a continuous gradient elution. The eluent was monitored at $254 \mathrm{~nm}$ and the running time was $10 \mathrm{~min}$. Standard curves for adenosine 5'-triphosphate (ATP) and each compound involved in its degradation pathway [adenosine 5'-diphosphate (ADP), adenosine 5'-monophosphate (AMP), inosine 5'-monophosphate (IMP), inosine (Ino) and hypoxanthine, $(\mathrm{Hx})$ ] were constructed in the 0 to $1 \mathrm{mM}$ range. All nucleotide standards were obtained from the Sigma Chemical Co. (St. Louis, MO). The widely used $\mathrm{K}$ value was calculated according to the following concentrations ratio: $\mathrm{K}$ value = $100 \mathrm{x}(\mathrm{Hx}+\mathrm{Ino}) /(\mathrm{ATP}+\mathrm{ADP}+\mathrm{AMP}+\mathrm{IMP}+\mathrm{Ino}+\mathrm{Hx})$.

\subsection{Statistical analyses}

Bacterial counts were transformed into log CFU/g before undergoing statistical analysis. The SPSS 11.5 for Windows software (SPSS Inc., Chicago, IL) was used to explore the statistical significance of the results obtained, this including multivariate contrasts and multiple comparisons by the Tukey test. A confidence interval at the $95 \%$ level $(P<0.05)$ was considered in all cases.

\section{Results and discussion}

\subsection{Sensory analyses}

The ray specimens stored in slurry ice exhibited overall good quality, being classified in the A category, up to day 6 (Table 1). After this sampling time, quality sharply decreased and on day 8 and 10 the ray specimens stored in slurry ice did not show acceptable quality. Remarkably, the main negative parameter linked to quality loss in the slurry ice batch corresponded to the external odour. The parameters that 
deserved the best scores in the ray specimens stored in slurry ice were the aspect of skin and gills as well as the flesh consistency and ventral side aspect.

On contrary, the overall A category of sensory quality was only maintained in the ray specimens stored in flake ice only during the first three days of storage, such ray specimens being rejected on day six (Table 2). The most relevant differences with respect to the slurry ice batch were observed in the flesh consistency and ventral side aspect, while the strong external ammonia odour also revealed as the limiting factor of acceptability in this batch. A detailed comparison between batches as regards their sensory quality allows concluding that ray exhibits a very limited shelf life, although this time was doubled as a consequence of processing in slurry ice. The slowing down of mechanisms involved in the formation of ammonia odour was the most remarkable advantage of storing ray in slurry ice. Such undesirable odours are associated to the degradation of proteins and non-protein-nitrogen (NPN) compounds (Read, 1968; Finne, 1992).

According to the results shown in this work, storage of ray in slurry ice allowed a significant extension of its shelf-life, confirming the results obtained with this refrigeration system with other aquatic food products such as turbot (Rodríguez, BarrosVelázquez, Piñeiro, Gallardo \& Aubourg, 2006), hake (Rodríguez, Losada, Aubourg \& Barros-Velázquez, 2004), horse mackerel (Rodríguez, Losada, Aubourg \& BarrosVelázquez, 2005), sardine (Campos, Rodríguez, Losada, Aubourg \& Barros-Velázquez, 2005) and shrimp (Huidobro, López-Caballero \& Mendes, 2002; Losada, Rodríguez, Miranda, Barros-Velázquez \& Aubourg, 2006).

\subsection{Microbiological analyses}

Table 3 compiles the most remarkable results concerning microbial growth in the muscle of ray specimens stored either in either slurry ice or flake ice. Statistically significant $(P<0.05)$ differences were observed at several sampling times between both batches for aerobic mesophiles and for psychrotrophic microorganisms.

In the case of the counts of total aerobic mesophiles, the average difference between batches was $0.62 \log$ units throughout storage. This difference was higher at advanced storage periods (day 8 and onwards), reaching a maximum value of 1.39 log units after 10 days of storage (Table 3). Although the total bacterial counts did not reach levels of $10^{7} \mathrm{CFU} / \mathrm{g}$, which are the minimum considered to be required for the spoilage of fish stored aerobically, storage of ray in slurry ice elicited a significant reduction. These results, to our knowledge the first referred to an elasmobranchious fish species, are quite in agreement with previous results obtained for lean fish species such as turbot (Rodríguez, Barros-Velázquez, Piñeiro, Gallardo \& Aubourg, 2006), medium-fat fish such as horse mackerel (Rodríguez, Losada, Aubourg \& Barros-Velázquez, 2005), and crustaceans such as shrimp (Losada, Rodríguez, Miranda, Barros-Velázquez \& Aubourg, 2006) stored in slurry ice as compared with counterpart batches stored in flake ice.

In the case of psychrotrophes, the average difference between batches along storage was $0.49 \log$ units. As in the case of the aerobic mesophiles, the difference between batches increased as the storage period progressed (day 6 and onwards), reaching a maximum value of $1.01 \mathrm{log}$ units after 10 days of storage (Table 3). The psychrotrophes counts reached levels slightly above $10^{7} \mathrm{CFU} / \mathrm{g}$ only in the flake ice batch, although this corresponded to a sampling time in which the sensory analyses had concluded the unacceptability of the batch. The counts determined for the psychrotrophes confirmed a more limited microbial growth in the slurry ice batch than in the flake ice batch, 
probably derived from the sub-zero temperature of storage, characteristic of the former refrigeration system. Interestingly, the differences observed in the psychrotrophes numbers were not as high as those observed for fatty acid fish species (Campos, Rodríguez, Losada, Aubourg \& Barros-Velázquez, 2005), and were more in agreement with those determined for lean fish species such as turbot (Rodríguez, BarrosVelázquez, Piñeiro, Gallardo \& Aubourg, 2006) or crustaceans (Losada, Rodríguez, Miranda, Barros-Velázquez \& Aubourg, 2006).

Microbial metabolites such as peptides or amino acids, derived from protein hydrolysis, contribute significantly to undesirable sensory changes in seafood products. Thus, undesirable modifications in odour, texture and appearance lead to the spoilage of seafood products (Shewan, 1977; Makarios-Laham \& Lee, 1993; Rodríguez, BarrosVelázquez, Ojea, Piñeiro \& Aubourg, 2003). Moreover, ray specimens exhibit a rapid post-mortem quality loss mainly derived from the activity of endogenous and microbial enzymes able to degrade proteins and NPN compounds (Vyncke, 1978; Finne, 1992), an undesirable event that limits the commercialization time of this elasmobranchious fish species. Accordingly, we investigated the evolution of proteolytic bacteria in the ray batches stored in slurry or flake ice, respectively. As can be observed in Table 3, statistically significant $(P<0.05)$ lower counts of proteolytic bacteria were observed in the slurry ice batch than in the flake ice batch only after 10 days of storage. However, the counts of proteolytic bacteria in ray muscle did not reach levels of $10^{4} \mathrm{CFU} / \mathrm{g}$ in both batches, this indicating a very limited activity of proteolytic bacteria in ray muscle. These results do not follow the pattern observed for other fish species such as hake (Rodríguez, Losada, Aubourg \& Barros-Velázquez, 2004), sardine (Campos, Rodríguez, Losada, Aubourg \& Barros-Velázquez, 2005), horse mackerel (Rodríguez, Losada, Aubourg \& Barros-Velázquez, 2005) or turbot (Rodríguez, Barros-Velázquez, Piñeiro, Gallardo \& Aubourg, 2006), cases where significant contributions of proteolytic bacteria to fish muscle spoilage were observed in the flake ice batches. Thus, the results presented in this study allows concluding that the contribution of proteolytic bacteria to the degradation of ray muscle seems to be very limited, and that the formation of ammonia compounds would rather be caused by a strong activity of endogenous nitrogen-degrading enzymes present in ray muscle.

\subsection{Chemical analyses}

Increases in $\mathrm{pH}$ indicate the accumulation of alkaline compounds by means of autolytic and microbial mechanisms (Hebard, Flick \& Martin, 1982). In our study on $\mathrm{pH}$, statistically significant $(P<0.05)$ differences were determined between both batches at all sampling times (Table 4). In this sense, the formation of urea, ammonia compounds and other alkaline metabolites provoked an important $\mathrm{pH}$ increase in the ray batch stored in flake ice, this leading to $\mathrm{pH}$ values as high as 9.0 after 10 days of storage (Table 4). On the other hand, the ray batch stored in slurry ice exhibited significantly lower $\mathrm{pH}$ values.

Interestingly, the $\mathrm{pH}$ value increases determined in muscle of ray specimens stored in slurry ice were far above those determined in other species such as turbot (Rodríguez, Barros-Velázquez, Piñeiro, Gallardo \& Aubourg, 2006), horse mackerel (Rodríguez, Losada, Aubourg \& Barros-Velázquez, 2005), sardine (Campos, Rodríguez, Losada, Aubourg \& Barros-Velázquez, 2005), hake (Rodríguez, Losada, Aubourg \& BarrosVelázquez, 2004) or crustaceans (Losada, Rodríguez, Miranda, Barros-Velázquez \& Aubourg, 2006), or with studies that had reported steady increases in $\mathrm{pH}$ for other fish 
species stored in conventional flake ice (Nunes, Batista \& Morâo de Campos, 1992; Ruíz-Capillas \& Moral, 2001).

The comparative evolution of TVB-N formation in ray muscle indicated statistically significant $(P<0.05)$ differences between batches at day 6 of storage and onwards (Table $4)$. Thus, and according to the results of this study, storage in slurry ice slowed down the formation of ammonia compounds in ray muscle as compared with flake ice. This reduction implied that after six days of storage the formation of TVB-N was reduced in a proportion of $45 \%$ (81.8 vs $149.5 \mathrm{mg} / 100 \mathrm{~g}$, respectively) as a consequence of processing in slurry ice (Table 4). Such results exhibited a completely different profile as compared with other fish species such as hake (Rodríguez, Losada, Aubourg \& Barros-Velázquez, 2004). As in the case of the $\mathrm{pH}$, the final TVB-N concentrations determined in ray muscle were far above the current levels usually determined in other fish species, such as hake, horse mackerel, sardine or turbot, a result that confirms the strong rate of spoilage mechanisms involved in the degradation of nitrogen compounds in this elasmobranchious fish species.

It should also be highlighted that TVB-N concentrations exhibited sharp increases along storage in both batches -although less important in the slurry ice batch-, while the microbial counts of proteolytic bacteria (Table 3) remained at low levels. This result points to a very limited contribution of microbial mechanisms to the formation of TVB$\mathrm{N}$ and to the development of ammonia odour in ray specimens, events that revealed as the limiting factors of shelf-life for this fish species. These results are not in agreement with the patterns determined for other fish species in which significant reductions in the numbers of proteolytic microorganisms correlated directly with significant reductions in the TVB-N concentrations and with a better $\mathrm{pH}$ control (Rodríguez, Losada, Aubourg \& Barros-Velázquez, 2004; Rodríguez, Losada, Aubourg \& Barros-Velázquez, 2005).

(Si crees que vale la pena, incluye algún comentario o cita del trabajo de G. Sol sobre TVB-N).

K value

Finally, the investigation of the autolytic degradation mechanisms, estimated by means of the rate of the nucleotide catabolism pathway (Figure )also revealed significant $(P<0.05)$ differences between batches in the formation of inosine and hypoxanthine, with average values of $43.3 \%$ and $54.0 \%$ being determined after six days of storage in the slurry ice and flake ice batches, respectively. In all cases, mean $\mathrm{K}$ values obtained for fish stored under flake ice were higher than uin their counterparts kept under slurry ice conditions.

TMA: Creo que es mejor no incluirla. Los datos no son buenos ni a nivel de lo que cabía esperar (visión tradicional) ni lo que salió en el de G. Sol, donde había un clara descenso con tiempo en ambos procesos.

\section{Conclusions}

The storage of ray specimens in slurry ice at subzero temperature allowed a better maintenance of their high quality, from three to six days, than in a counterpart batch stored in flake ice. The formation of ammonia compounds, with the subsequent negative effect at the sensory level, revealed as the limiting factor of acceptability of the ray batches. The contribution of the proteolytic microorganisms to the formation of urea and other ammonia compounds resulted to be rather limited, these compounds mainly 
being derived from the endogenous nitrogen-degrading enzymatic complexes present in ray muscle. The enhanced maintenance of quality derived from processing in slurry ice may allow the commercialization of refrigerated ray specimens with better guarantees of quality and safety.

\section{Acknowledgements}

The authors wish to thank KINARCA S.A.U. for providing the slurry ice equipment. This work was supported by a project granted by the Secretaría Xeral de I+D from the Xunta de Galicia (Project PGIDIT04TAL015E). The authors also thank Mr. Marcos Trigo and Mr. José M. Antonio (AQUí, NO) for their excellent technical assistance.

\section{References}

FAO. (2006). Fishery statistics. Capture production. Food and Agriculture Organization of the United Nations, Rome (Italy). Yearbook 2004. Vol. 98/1, pp. 139, 224, and 306.

Pastoriza, L., \& Sampedro, G. (1994). Influence of ice storage on ray (Raja clavata) wing muscle. Journal of the Science of Food and Agriculture, 64, 9-18.

Xunta de Galicia (2001). Fishing bank location. Santiago de Compostela, Galicia, Spain. Available: http://www.xunta.es/conselle/pe/castellano/caladorios.htm.

Aubourg, S. P., Losada, V., Prado, M., Miranda, J. M., \& Barros-Velázquez, J. (2007). Improvement of the commercial quality of chilled Norway lobster (Nephrops norvegicus) stored in slurry ice: Effects of a preliminary treatment with antimelanosic agent of enzymatic browning. Food Chemistry, (in the press).

Aubourg, S., Sotelo, C., \& Gallardo, J. (1997). Quality assessment of sardines during storage by measurement of fluorescent compounds. Journal of Food Science, 62, 295-299.

Ben-Gigirey, B., Vieites Baptista de Sousa, J. M., Villa, T. G., \& Barros-Velázquez, J. (1998). Changes in biogenic amines and microbiological analysis in albacore (Thunnus alalunga) muscle during frozen storage. Journal of Food Protection, 61, 608-615.

Ben-Gigirey, B., Vieites Baptista de Sousa, J. M., Villa, T. G., \& Barros-Velázquez, J. (1999). Histamine and cadaverine production by bacteria isolated from fresh and frozen albacore (Thunnus alalunga). Journal of Food Protection, 62, 933-939.

Ben-Gigirey, B., Vieites Baptista de Sousa, J. M., Villa, T. G., \& Barros-Velázquez, J. (2000). Characterization of biogenic amine-producing Stenotrophomonas maltophilia strains isolated from white muscle of fresh and frozen albacore tuna. International Journal of Food Microbiology, 57, 19-31.

Campos, C., Rodríguez, Ó., Losada, V., Aubourg, S., \& Barros-Velázquez, J. (2005). Effects of storage in ozonised slurry ice on the sensory and microbial quality of sardine (Sardina pilchardus). International Journal of Food Microbiology, 103, 121-130.

Chapman, L. (1990). Making the grade. Ice slurries get top marks for quality products. Australian Fisheries, 7, 16-19. 
Chinivasagam, H. N., Bremner, H. A., Wood, A. F., \& Nottingham, S. M. (1998). Volatile components associated with bacterial spoilage of tropical prawns. International Journal of Food Microbiology, 42, 45-55.

DOCE (1989). Baremo de clasificación de frescura. Brussels: European Comission.

Hebard, C. E., Flick, G. J., \& Martin, R. E. (1982). Occurrence and significance of trimethylamine oxide and its derivatives in fish and shellfish. In R. E. Martin, G. J. Flick, C. E. Hebard, \& D. R. Ward, Chemistry and biochemistry of marine food products (pp. 149-304). Westport, Connecticut: Avi.

Huidobro, A., López-Caballero, M., \& Mendes, R. (2002). Onboard processing of deepwater pink shrimp (Parapenaeus longirostris) with liquid ice: Effect on quality. European Food Research and Technology, 214, 469-475.

Kraus, L. (1992). Refrigerated sea water treatment of herring and mackerel for human consumption. In J. Burt, R. Hardy, \& K. Whittle, Pelagic fish. The resource and its exploitation (pp. 73-81). Aberdeen, Scotland (UK): Fishing News Books.

Losada, V., Rodríguez, O., Miranda, J. M., Barros-Velázquez, J., \& Aubourg, S. P. (2006). Development of different damage pathways in Norway lobster (Nephrops norvegicus) stored under different chilling systems. European Journal of the Science of Food and Agriculture, 86, 1552-1558.

Losada, V., Barros-Velázquez, J., Gallardo, J., \& Aubourg, S. (2004). Effect of advanced chilling methods on lipid damage during sardine (Sardina pilchardus) storage. European Journal of Lipid Science and Technology, 106, 844-850.

Losada, V., Piñeiro, C., Barros-Velázquez, J., \& Aubourg, S. (2004). Effect of slurry ice on chemical changes related to quality loss during European hake (Merluccius merluccius) chilled storage. European Food Research and Technology, 219, 2731.

Martinsdöttir, E., Valdimarsdöttir, P., Porkelsdöttir, A., Olafsdöttir, G., \& Tryggvadöttir, S V. (2002). Shelf life of sea bass (Dicentrarchus labrax) in liquid and flake ice studied by quality index method (QIM), electronic nose and texture. In Proceedings of the 32nd annual WEFTA meeting. Galway, Ireland.

Makarios-Laham, I. K., \& Lee, T. C. (1993). Protein hydrolysis and quality deterioration of refrigerated and frozen seafood due to obligately psychrophilic bacteria. Journal of Food Science, 58, 310-313.

Nunes, M., Batista, I., \& Morâo de Campos, R. (1992). Physical, chemical and sensory analysis of sardine (Sardina pilchardus) stored in ice. Journal of the Science of Food and Agriculture, 59, 37-43.

Olafsdöttir, G., Martinsdöttir, E., Oehlenschläger, J., Dalgaard, P., Jensen, B., Undeland, I., Mackie, I., Henehan, G., Nielsen, J. \& Nilsen, H. (1997). Methods to evaluate fish freshness in research and industry. Trends in Food Science and Technology, 8, 258-265.

Phaff, H.J., Starmer, W. T., Lachance, M. A., \& Ganter, P. F. (1994). Candida caseinolytica sp. nov., a new species of yeast occurring in necrotic tissues of Opuntia and Stenocereus species in the Southwestern United States and Baja California, Mexico. International Journal of Systematic Bacteriology, 44, 641-645.

Piñeiro, C., Barros-Velázquez, J., \& Aubourg, S.P. (2004). Effects of newer slurry ice systems on the quality of aquatic food products: a comparative review versus flake ice chilling methods. Trends in Food Science and Technology, 15, 575582.

Price, R. J., Melvin, E F., \& Bell, J. W. (1991). Postmortem changes in chilled round, bled and dressed albacore. Journal of Food Science, 56, 318-321. 
1 Rodríguez, O., Barros-Velázquez, J., Ojea, A., Piñeiro, C., \& Aubourg, S. (2003). Evaluation of sensory and microbiological changes and identification of proteolytic bacteria during the iced storage of farmed turbot (Psetta maxima). Journal of Food Science, 68, 2764-2771.

Rodríguez, Ó., Barros-Velázquez, J., Piñeiro, C., Gallardo, J., \& Aubourg, S. (2006). Effects of storage in slurry ice on the microbial, chemical and sensory quality and on the shelf life of farmed turbot (Psetta maxima). Food Chemistry, 95, 270-278.

Rodríguez, O., Losada, V., Aubourg, S., \& Barros-Velázquez, J. (2004). Enhanced shelf-life of chilled European hake (Merluccius merluccius) stored in slurry ice as determined by sensory analysis and assessment of microbiological activity. Food Research International, 37, 749-757.

Rodríguez, Ó, Losada, V., Aubourg, S., \& Barros-Velázquez, J. (2005). Sensory, microbial and chemical effects of a slurry ice system on horse mackerel (Trachurus trachurus). Journal of the Science of Food and Agriculture, 85, 235-242.

Ruíz-Capillas, C., \& Moral, A. (2001). Correlation between biochemical and sensory quality indices in hake stored in ice. Food Research International, 34, 441-447.

Ryder, J. (1985). Determination of adenosine triphosphate and its breakdown products in fish muscle by high performance liquid chromatography. Journal of Agriculture and Food Chemistry, 33, 678-680.

Shewan, J. M. (1977). The bacteriology of fresh and spoiling fish and the biochemical changes induced by bacterial action. In Handling, processing and marketing of tropical fish (pp. 51-68). London, UK: Tropical Product Institute.

Whittle, K., Hardy, R., \& Hobbs, G. (1990). Chilled fish and fishery products. In Gormley, T., Chilled foods: the state of the art (pp. 87-116). New York, USA: Elsevier Applied Science. 
Table 1

Scale employed for evaluating the freshness of ray specimens along storage

\begin{tabular}{|c|c|c|c|c|}
\hline Attribute & $\begin{array}{l}\text { Highest quality } \\
\text { (E) }\end{array}$ & $\begin{array}{l}\text { Good quality } \\
\text { (A) }\end{array}$ & $\begin{array}{l}\text { Fair quality } \\
\text { (B) }\end{array}$ & $\begin{array}{l}\text { Unacceptable } \\
\text { (C) }\end{array}$ \\
\hline Skin & $\begin{array}{l}\text { Shiny and very } \\
\text { intense } \\
\text { pigmentation; } \\
\text { transparent } \\
\text { mucus }\end{array}$ & $\begin{array}{c}\text { Intense } \\
\text { pigmentation } \\
\text { transparent } \\
\text { mucus }\end{array}$ & $\begin{array}{l}\text { Shineless and } \\
\text { decoloured } \\
\text { pigmentation; } \\
\text { opaque mucus }\end{array}$ & $\begin{array}{c}\text { Decoloured } \\
\text { skin; abundant } \\
\text { and opaque } \\
\text { mucus }\end{array}$ \\
\hline Eyes & $\begin{array}{l}\text { Convex and } \\
\text { shiny; small } \\
\text { pupil }\end{array}$ & $\begin{array}{c}\text { Convex and } \\
\text { slightly sunken; } \\
\text { oval pupil }\end{array}$ & $\begin{array}{c}\text { Flat; opaque } \\
\text { pupil }\end{array}$ & $\begin{array}{c}\text { Concave and } \\
\text { yellowish }\end{array}$ \\
\hline Gills & $\begin{array}{c}\text { Brightly red; } \\
\text { without odour; } \\
\text { lamina perfectly } \\
\text { separated }\end{array}$ & $\begin{array}{l}\text { Rose coloured; } \\
\text { without odour; } \\
\text { lamina adhered } \\
\text { in groups }\end{array}$ & $\begin{array}{l}\text { Slightly pale; } \\
\text { incipient fishy } \\
\text { odour; lamina } \\
\text { adhered in } \\
\text { groups }\end{array}$ & $\begin{array}{c}\text { Grey-yellowish } \\
\text { colour; intense } \\
\text { ammonia odour; } \\
\text { lamina totally } \\
\text { adhered }\end{array}$ \\
\hline $\begin{array}{l}\text { Flesh } \\
\text { consistency and } \\
\text { ventral side } \\
\text { aspect }\end{array}$ & $\begin{array}{c}\text { Firm and elastic } \\
\text { flesh; presence } \\
\text { or partial } \\
\text { disappearance } \\
\text { of rigor mortis } \\
\text { symptoms; } \\
\text { curvy flaps; } \\
\text { white and shiny } \\
\text { ventral side }\end{array}$ & $\begin{array}{c}\text { Firm flesh; } \\
\text { pressure signs } \\
\text { disappear } \\
\text { immediately } \\
\text { and completely; } \\
\text { rigid flaps; } \\
\text { white and shiny } \\
\text { ventral side } \\
\text { with red stains }\end{array}$ & $\begin{array}{c}\text { Soft flesh; } \\
\text { presence of } \\
\text { mechanical } \\
\text { signs; elasticity } \\
\text { notably } \\
\text { reduced; soft } \\
\text { flaps; shineless } \\
\text { ventral side } \\
\text { with red and } \\
\text { yellowish stains }\end{array}$ & $\begin{array}{c}\text { Flaccid flesh; } \\
\text { internal organs } \\
\text { blurred; flaccid } \\
\text { flaps; yellowish } \\
\text { to greenish } \\
\text { ventral side } \\
\text { with red stains }\end{array}$ \\
\hline External odour & $\begin{array}{c}\text { Sharply } \\
\text { seaweedy smell }\end{array}$ & $\begin{array}{c}\text { Weakly } \\
\text { seaweedy non- } \\
\text { ammonia odour }\end{array}$ & $\begin{array}{l}\text { Incipiently sour } \\
\text { and ammonia } \\
\text { odour }\end{array}$ & $\begin{array}{c}\text { Intense } \\
\text { ammonia odour }\end{array}$ \\
\hline
\end{tabular}


Table 2

Comparative sensory acceptability of ray batches ${ }^{\mathrm{a}}$

\begin{tabular}{lc|cccc|cccc}
\hline & \multicolumn{3}{c}{$\begin{array}{c}\text { Flake ice batch } \\
\text { Initial }\end{array}$} & \multicolumn{4}{c}{$\begin{array}{c}\text { Slurry ice batch } \\
\text { (days of storage) }\end{array}$} & \multicolumn{3}{c}{ (days of storage) } \\
\cline { 2 - 9 } & 0 & 3 & 6 & 8 & 10 & 3 & 6 & 8 & 10 \\
\hline Skin aspect & E & A & B & B & C & A & A & B & B \\
Eyes & E & A & B & B & C & A & A & B & C \\
Gills & E & A & B & B & C & A & A & B & B \\
Flesh/ventral side & E & B & B & C & C & A & A & B & C \\
External odour & E & B & C & C & C & A & B & C & C \\
\hline
\end{tabular}

${ }^{\mathrm{a}}$ Freshness categories are as expressed in Table 1. 
Table 3

Comparative microbial growth of different microbial groups in the muscle of ray specimens stored in flake ice (FI) or in slurry ice (SI)

\begin{tabular}{|c|cc|ccc|cc|}
\hline \multirow{2}{*}{$\begin{array}{c}\text { Storage time } \\
\text { (days) }\end{array}$} & \multicolumn{2}{|l}{ Aerobic mesophiles } & \multicolumn{2}{l}{ Psychrotrophes } & \multicolumn{2}{c|}{ Proteolytic bacteria } \\
\cline { 2 - 7 } & FI & SI & FI & SI & FI & SI \\
\hline 3 & $4.70 \mathrm{a}$ & $4.66 \mathrm{a}$ & $5.18 \mathrm{a}$ & $5.16 \mathrm{a}$ & $3.23 \mathrm{a}$ & $3.29 \mathrm{a}$ \\
& $(4.65-5.16)$ & $(4.51-4.76)$ & $(5.02-5.38)$ & $(5.01-5.38)$ & $(3.05-3.38)$ & $(3.03-3.49)$ \\
\cline { 2 - 7 } 6 & $5.04 \mathrm{a}$ & $4.94 \mathrm{a}$ & $5.64 \mathrm{~b}$ & $5.29 \mathrm{a}$ & $3.34 \mathrm{a}$ & $3.28 \mathrm{a}$ \\
& $(4.83-5.16)$ & $(4.78-5.05)$ & $(5.46-5.89)$ & $(5.19-5.42)$ & $(3.15-3.52)$ & $(3.04-3.56)$ \\
\cline { 2 - 7 } 8 & $6.25 \mathrm{~b}$ & $5.31 \mathrm{a}$ & $6.07 \mathrm{~b}$ & $5.48 \mathrm{a}$ & $3.01 \mathrm{a}$ & $2.95 \mathrm{a}$ \\
& $(6.14-6.56)$ & $(5.18-5.51)$ & $(5.97-6.23)$ & $(5.23-5.78)$ & $(2.76-3.45)$ & $(2.67-3.05)$ \\
\cline { 2 - 7 } 10 & $6.62 \mathrm{~b}$ & $5.23 \mathrm{a}$ & $7.02 \mathrm{~b}$ & $6.01 \mathrm{a}$ & $3.35 \mathrm{~b}$ & $2.88 \mathrm{a}$ \\
& $(6.41-7.01)$ & $(4.88-5.46)$ & $(6.92-7.17)$ & $(5.87-6.32)$ & $(3.13-3.53)$ & $(2.68-3.07)$ \\
\hline
\end{tabular}

Average counts followed by different letters are statistically different $(P<0.05)$.

Ranges are indicated between brackets. 
Table 4

Comparative evolution of $\mathrm{pH}$ and TVB-N in the muscle of ray specimens stored in flake ice (FI) or in slurry ice (SI)

\begin{tabular}{|c|c|c|c|c|}
\hline \multirow{2}{*}{$\begin{array}{c}\text { Storage time } \\
\text { (days) }\end{array}$} & \multicolumn{2}{|c|}{$\mathrm{pH}$} & \multicolumn{2}{c|}{$\begin{array}{c}\text { TVB-N } \\
(\mathrm{mg} / 100 \mathrm{~g})\end{array}$} \\
\cline { 2 - 5 } & $\mathrm{FI}$ & $\mathrm{SI}$ & $\mathrm{FI}$ & $\mathrm{SI}$ \\
\hline 3 & $6.92 \mathrm{~b}$ & $6.70 \mathrm{a}$ & $55.9 \mathrm{a}$ & $52.5 \mathrm{a}$ \\
& $(0.03)$ & $(0.05)$ & $(4.72)$ & $(8.22)$ \\
\hline 6 & $8.68 \mathrm{~b}$ & $7.46 \mathrm{a}$ & $149.5 \mathrm{~b}$ & $81.8 \mathrm{a}$ \\
& $(0.18)$ & $(0.22)$ & $(3.67)$ & $(11.3)$ \\
\hline 8 & $8.96 \mathrm{~b}$ & $8.67 \mathrm{a}$ & $208.8 \mathrm{~b}$ & $131.5 \mathrm{a}$ \\
& $(0.06)$ & $(0.17)$ & $(3.88)$ & $(2.13)$ \\
\hline 10 & $9.00 \mathrm{~b}$ & $8.49 \mathrm{a}$ & $206.9 \mathrm{~b}$ & $125.9 \mathrm{a}$ \\
& $(0.02)$ & $(0.24)$ & $(3.91)$ & $(2.08)$ \\
\hline
\end{tabular}

Average counts followed by different letters are statistically different $(P<0.05)$.

Standard deviation values are indicated between brackets. 


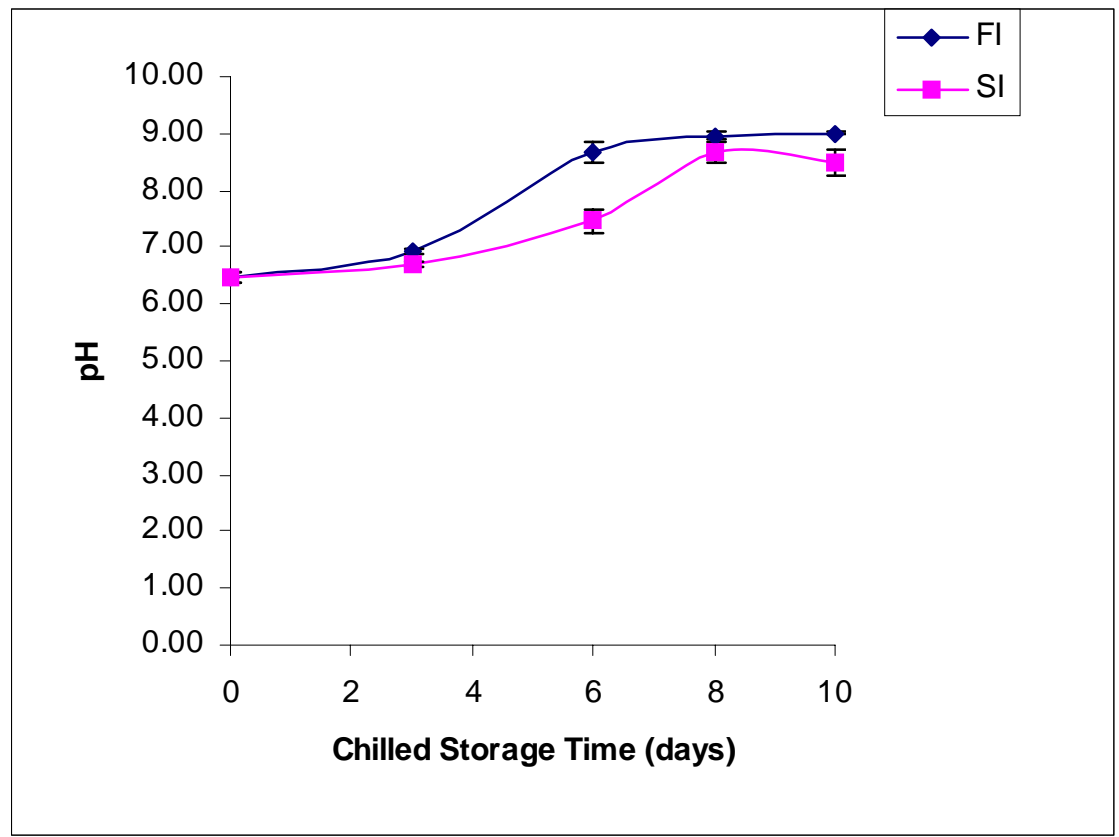

Figura 1

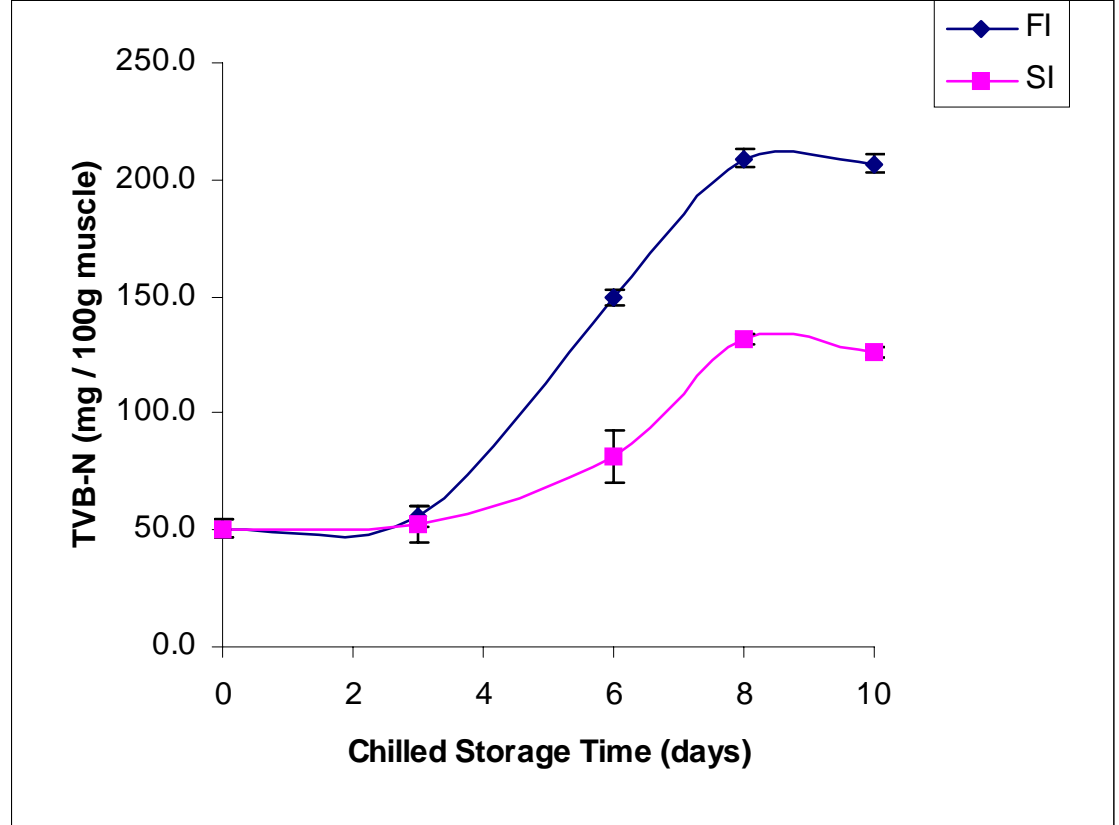

Figura 2 


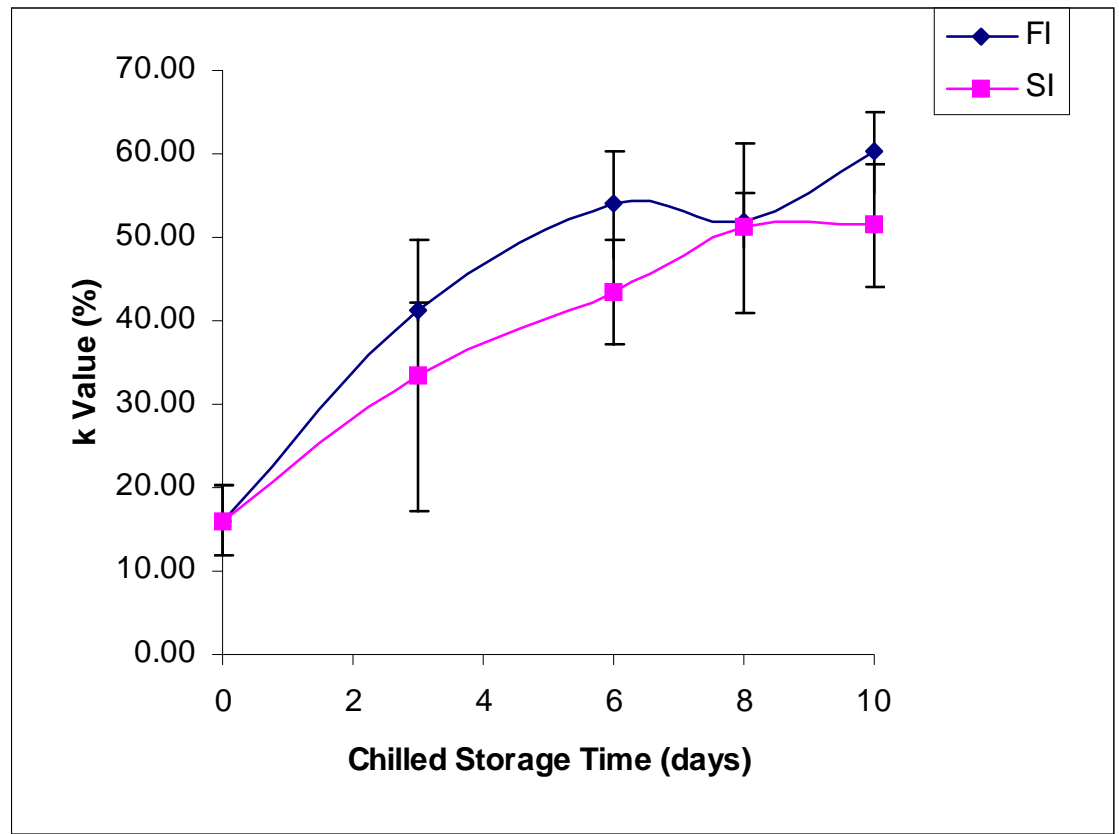

Figura 3 